\title{
PENERAPAN ASAS ITIKAD BAIK DALAM PERJANJIAN KERJA SAMA PENGELOLAAN MANAGEMENT ANTARA PT CITILINK INDONESIA (GARUDA GROUP) DENGAN PT SRIWIJAYA AIR DAN PT NAM AIR (SRIWIJAYA GROUP)
}

\author{
NOVA \\ Manager Legal PT SJY Tangerang Banten \\ novatampubolon.nt@gmail.com
}

\begin{abstract}
ABSTRAK
Perekonomian di Indonesia khususnya dalam bidang usaha penerbangan kian hari kian mengalami perkembangan yang cukup pesat. Tidak dapat dipungkiri pelaku usaha dan para stakeholder di dunia usaha penerbangan (aviation) melakukan berbagai macam bentuk kerja sama guna mempertahankan bisnisnya. Salah satu bentuk kerja sama yang nyata adalah Kerja Sama Pengelolaan Management (KSM) sebagaimana diinisiasi antara Sriwijaya Group dan Garuda Group. Sehubungan dengan pelaksanaan KSM tersebut, dimana dalam perjanjian kerja sama diatur mengenai penempatan personil dari Garuda Group dalam susunan manajemen Sriwijaya Group, khususnya dalam susunan organ perseroan (Direksi dan Dewan Komisaris), yang berujung lahirnya benturan kepentingan dari personil Garuda Group yang ditempatkan dalam susunan organ perseroan Sriwijaya Group. Pentingnya profesionalisme yang didasari oleh asas itikad baik sebagaimana bunyi Pasal 1338 ayat (3) KUH Perdata dalam pelaksanaan fungsi dan wewenang dari organ perseroan sangatlah dituntut demi terlaksananya tujuan kerja sama. Berdasarkan uraian dari latar belakang Perjanjian KSM, bagaimana seharusnya Direksi dan Dewan Komisaris yang adalah personil Garuda Group bertindak dalam kaitannya dengan prinsip Business Judgment Rule (BJR) sebagai cerminan pelaksanaan atas itikad baik dan tindakan antisipasi apa yang harus dilakukan oleh Para Pemegang Saham Sriwijaya Group berkaitan dengan pelaksanaan KSM agar dapat berjalan dengan baik sesuai dengan tujuan awal kerja sama. Metode Penelitian ini adalah penelitian kepustakaan dengan menggunakan metode analisis deskriptif yaitu dengan jalan mengumpulkan data, menyusun dan mengklarifikasi serta menginterpretasikannya dengan merujuk pada prinsip dan asas hukum. Kecenderungan diabaikannya prinsip BJR sebagai cerminan dari pelaksanaan asas itikad baik dapat menghambat terwujudnya KSM. Penandatanganan amandemen II dan III perjanjian KSM oleh Direksi Sriwijaya Group yang merupakan orang-orang Garuda Group tanpa melalui persetujuan lebih dahulu dari Para Pemegang Saham Sriwijaya Group merupakan salah satu bentuk pengabaian asas itikad baik. Terkait pembuatan dan pelaksanaan perjanjian KSM perlu adanya pengaturan yang jelas dari klausul-klausul yang ada dalam perjanjian KSM, termasuk perlu adanya pengaturan mengenai tugas dan wewenang organ perseroan secara terperinci sehingga dapat menjadi salah satu kontrol dari kemungkinan adanya keputusan bisnis perusahaan yang tidak didasarkan atas kepentingan perseroan Sriwijaya Group.
\end{abstract}

Kata Kunci: Perjanjian Kerja Sama Pengelolaan Management Antara Garuda Group dan Sriwijaya Group 


\begin{abstract}
Currently, the economy in Indonesia, especially in the aviation business sector, is experiencing rapid development. It is undeniable that business actors and stakeholders in the aviation world have carried out various forms of cooperation in order to maintain their business. One of the real forms of cooperation is Management Cooperation (KSM) as initiated between Sriwijaya Group and Garuda Group. In connection with implementation of KSM, the cooperation agreement regulates a placement of personnel from Garuda Group in Sriwijaya Group's management structure, especially in the composition of the company's organs (Board of Directors and Board of Commissioners), which results in a conflict of interest from Garuda Group personnel who are placed in the composition of Sriwijaya Group' organs. The importance of professionalism which is based on the principle of good faith as stated in Article 1338 paragraph (3) of the Civil Code in implementation of the functions and the authorities of the company's organs is highly demanded for implementation of cooperation objectives. Based on the description of the background of KSM Agreement, the Board of Directors and the Board of Commissioners who are Garuda Group personnel should act in accordance with the principles of the Business Judgment Rule (BJR) as a reflection of implementation of good faith and anticipatory actions that must be taken by the Shareholders of Sriwijaya Group in relation with the implementation of KSM so that it can run well in accordance with the initial objectives of the cooperation. This research method is library research using descriptive analysis, namely by collecting data, compiling and clarifying and interpreting them by referring to the principles of law. The tendency to ignore the BJR principles as a reflection of implementation of the principle of good faith can hinder the realization of KSM. The signing of the II and III amendments to KSM agreement by the Board of Directors of Sriwijaya Group who are Garuda Group members without prior approval from the Shareholders of Sriwijaya Group is a form of neglecting the principle of good faith. Regarding the making and implementation of the KSM agreement, there needs to be a clear arrangement of the clauses in the KSM agreement, including the need for detailed arrangements regarding the duties and the authorities of the company's organs so that they can be one of the controls for the possibility of company business decisions that are not based on interests of Sriwijaya Group.
\end{abstract}

Keyword: Management Cooperation Agreement Between Garuda Group and Sriwijaya Group

\title{
PENDAHULUAN
}

Perekonomian di Indonesia kian hari kian mengalami berkembang yang cukup pesat. Berbagai macam bidang usaha turut mendorong perkembangan bisnis di Indonesia, salah satu diantaranya adalah bidang usaha penerbangan (aviation). Kesuksesan Orville Wright dan Wilbur Wright bersaudara sebagai pencetus burung besi yang terbang pertama kalinya pada tahun 1903 patut menjadi apresiasi yang membuka cakrawala dunia bagi bisnis penerbangan baik di dunia internasional maupun di Indonesia. Indonesia merupakan negara kepulauan, tidak dapat dipungkiri bahwa penerbangan sebagai moda transportasi udara di Indonesia memiliki peranan yang cukup penting guna mendukung kegiatan bisnis dan perekonomian dalam menghubungkan daerah-daerah yang belum dapat dijangkau dengan moda transportasi lain. Transportasi udara menjadi pilihan terbaik guna efektifitas dan efisiensi waktu tempuh perjalanan baik domestik maupun internasional. 
Di Indonesia khususnya, industri penerbangan dalam hal ini yang dimaksudkan adalah penerbangan komersil yang telah dimulai sejak awal tahun 1949 dan merupakan tonggak sejarah bagi penerbangan komersial di Indonesia sampai dengan perkembangannya saat ini. Perkembangan yang sangat pesat dalam dunia penerbangan dimaksud tidak terlepas dari proses perubahan yang terus menerus dilakukan oleh para pelaku usaha dan seluruh stackeholder terkait bisnis penerbangan, hal ini dapat dilihat dari banyaknya maskapai penerbangan yang melayani jasa angkutan udara dari dan ke berbagai rute penerbangan baik domestik maupun internasional. Transportasi udara tidak lagi merupakan barang mewah yang hanya dapat dinikmati oleh masyarakat kalangan atas. Banyak maskapai penerbangan yang menyediakan harga tiket yang terjangkau untuk berbagai kalangan dengan masing-masing keunggulan pelayanan yang dimiliki.

Bisnis maskapai penerbangan merupakan usaha yang high cost (biaya tinggi) dan high risk (beresiko tinggi), sehingga tidak dapat dipungkiri bahwa di Indonesia khususnya perusahaan maskapai penerbangan sering kali mengalami pasang surut. Dapat dikatakan bahwa bisnis maskapai penerbangan memerlukan bisnis yang membutuhan modal atau biaya yang cukup tinggi untuk menjaga kelangsungan usaha atau kelangsungan bisnis maskapai penerbangan itu sendiri. Berbagai bentuk kerja sama tercipta guna mendukung kelangsungan usaha maskapai penerbangan. Para stackeholder di bidang maskapai penerbangan berusaha dengan berbagai daya dan upaya mempertahankan agar bisnis maskapai penerbangannya tetap dapat berjalan dengan tanpa mengesampingkan keselamatan penumpangnya.

Berbagai bentuk kerja sama diinisiasi oleh para pelaku usaha maskapai penerbangan. Sebutkan saja sebagai salah satu contohnya adalah kerja sama yang dilakukan antara PT Sriwijaya Air dan PT NAM Air (Sriwijaya Group) dengan PT Citilink Indonesia (Garuda Group) dalam Perjanjian Kerja Sama Operasi Nomor CITILINK/JKTDSQG/PERJ-6274/1118 Tanggal 09 November 2018 antara PT Citilink Indonesia dengan PT Sriwijaya Air dan PT NAM Air (Perjanjian "KSO"), yang telah diubah seluruhnya dengan Perjanjian Perubahan dan Pernyataan Kembali Perjanjian Kerja Sama Operasi Nomor CITILINK/JKTDSQG/AMAND-I/6274/1118 Tanggal 19 November 2018 antara PT Citilink Indonesia dengan PT Sriwijaya Air dan PT NAM Air (Perjanjian "KSM"). Kerja sama KSM tersebut dilaksanakan awalnya bertujuan untuk menyehatkan kondisi finansial Sriwijaya Group yang nantinya apabila kondisi finansial Sriwijaya Group telah membaik diharapkan Sriwijaya Group dapat dengan lancar menyelesaikan kewajiban pembayaran utangnya kepada PT Garuda Maintenance Facility Aero Asia Tbk (Garuda Group) atas hutang perbaikan dan perawatan pesawat Sriwijaya Group yang cukup besar kepada PT Garuda Maintenance Facility Aero Asia Tbk (Garuda Group). Guna mencapai tujuan bersama tersebut antara Sriwijaya Group dan Garuda Group akhirnya disepakatilah adanya kerja sama KSO yang diubah menjadi KSM oleh Sriwijaya Group yang diwakili oleh Direktur Utama yang juga adalah pemegang saham PT Sriwijaya Air dan Direktur PT NAM Air dengan Direktur Utama PT Citilink Indonesia (Garuda Group). 


\section{PENDEKATAN TEORI}

Penelitian ini menggunakan metode pendekatan hukum normatif. Penelitian hukum normatif adalah metode penelitian hukum yang dilakukan dengan meneliti bahan pustaka atau data sekunder.

Dalam kaitannya dengan pendekatan normative, penelitian ini menggunakan beberapa pendekatan:

1. Pendekatan perundang-undangan (statute approach) adalah suatu pendekatan yang dilakukan terhadap berbagai aturan hukum yang berkaitan dengan Undang-Undang Nomor 40 Tahun 2007 Tentang Perseroan Terbatas.

2. Pendekatan konseptual (conceptual approach) adalah suatu pendekatan yang dilakukan dengan beranjak dari pandangan-pandangan dan doktrin-doktrin yang berkembang dalam ilmu hukum.

3. Pendekatan komparatif (comparative approach) yaitu dengan membandingkan antara kondisi setelahnya dan kondisi sebelumnya. Perbandingan dilakukan untuk memperoleh persamaan dan perbedaan guna mendukung argumen yang dibangun oleh peneliti.

\section{METODE PENELITIAN}

\section{Sifat Penelitian}

Penelitian ini adalah penelitian kepustakaan (library research) dengan menggunakan metode penelitian hukum normatif terapan. Penelitian hukum normatif terapan adalah penelitian hukum yang meliputi dan mengkaji pemberlakuan atau implementasi ketentuan normatif (kodifikasi, undang-undang atau kontrak) secara in-action pada setiap peristiwa hukum tertentu yang terjadi dalam masyarakat guna mencapai tujuan yang telah ditentukan. ${ }^{1}$

\section{Teknik Pengumpulan Data}

Dalam pengumpulan bahan hukum ini, dilakukan dengan mengumpulkan terlebih dahulu data-data dengan cara mempelajari bahan hukum primer, bahan hukum sekunder dan bahan hukum tersier. Pengumpulan data dalam penelitian ini dilakukan dengan cara-cara sebagai berikut:

a. Studi kepustakaan (library research), yaitu studi yang dilakukan dengan cara mempelajari buku-buku, peraturan perundang-undangan serta dokumen lainnya yang mendukung penulisan ini.

b. Studi dokumen, yaitu studi yang dilakukan dengan cara membaca, menelaah, dan mengkaji dokumen yang menjadi objek penelitian ini yaitu dokumen Perjanjian Kerja Sama Pengelolaan Management antara PT Citilink Indonesia (Garuda Group) dengan PT Sriwijaya Air dan PT NAM Air (Sriwijaya Group) beserta amandemen II dan III nya.

Pengumpulan dokumen perjanjian dilakukan Peneliti dengan pengumpulan dokumendokumen yang dimiliki oleh Sriwijaya Air Group terkait Kerja Sama Pengelolaan

\footnotetext{
${ }^{1}$ Abdulkadir Muhammad, Hukum dan Penelitian Hukum, (Bandung: PT Citra Aditya Bakti, 2004), hlm. 2.
} 
Management dengan PT Citilink Indonesia (Garuda Group), dimana Peneliti adalah pegawai di Sriwijaya Air Group yang bertugas dibagian Legal Sriwijaya Air Group.

Selain itu juga Peneliti mengumpulkan literatur-literatur kepustakaan yang dapat mendukung argumen Peneliti dalam membahas pokok masalah yang telah dirumuskan oleh Peneliti.

\section{Teknik Penyajian Data}

Peneliti melakukan penyajian data dalam bentuk tulisan sebenarnya yang merupakan gambaran umum tentang kesimpulan hasil penelitian.

\section{Teknik Analisis Data}

Data yang terkumpul dan tersusun secara sistematis kemudian dianalisis secara kualitatif yaitu analisis yang dilakukan dengan cara merekonstruksi atau menginterpretasikan data dalam bentuk kalimat sistematis dan dalam bahasa yang efektif dengan menghubungkan data tersebut menurut pokok bahasan yang telah ditetapkan, sehingga diperoleh data menurut pokok bahasan yang ditetapkan, sehingga diperoleh gambaran yang jelas untuk mengambil suatu keputusan terhadap permasalahan yang akan diteliti yaitu Penerapan Asas Itikad Baik Dalam Perjanjian Kerja Sama Pengelolaan Management antara PT Citilink Indonesia (Garuda Group) dengan PT Sriwijaya Air dan PT Nam Air (Sriwijaya Group).

\section{HASIL PEMBAHASAN}

Bermula dari adanya hutang Sriwijaya Group kepada PT Garuda Maintenance Facility Aero Asia Tbk (GMF) yang merupakan bagian dari Garuda Group, atas kerja sama perawatan pesawat milik Sriwijaya Group yang berakibat Sriwijaya Group memiliki hutang kepada Garuda Group. Atas kondisi tersebut akhirnya diinisiasilah adanya suatu kerja sama antara Sriwijaya Group dan Garuda Group dengan tujuan awal untuk membantu menyehatkan kondisi finansial Sriwijaya Group melalui kerja sama sebagaimana dituangkan dalam Perjanjian Kerja Sama Operasional yang kemudian diubah menjadi Perjanjian Kerja Sama Pengelolaan Management oleh dan antara Sriwijaya Group dan PT Citilink Indonesia (Garuda Group) sebagaimana tertuang dalam Perjanjian Kerja Sama Operasi Nomor CITILINK/JKTDSQG/PERJ-6274/1118 Tanggal 09 November 2018 antara PT Citilink Indonesia dengan PT Sriwijaya Air dan PT NAM Air (Perjanjian "KSO"), yang telah diubah seluruhnya dengan Perjanjian Perubahan dan Pernyataan Kembali Perjanjian Kerja Sama Operasi Nomor CITILINK/JKTDSQG/AMAND-I/6274/1118 Tanggal 19 November 2018 antara PT Citilink Indonesia dengan PT Sriwijaya Air dan PT NAM Air (Perjanjian 'KSM").

Setelah dilakukan penandatanganan Perjanjian KSM antara Direktur Utama PT Sriwijaya Air yang diwakili oleh Bapak Chandra Lie yang juga merupakan pemegang saham perseroan dan Direktur PT NAM Air yang diwakili oleh Bapak Jefferson Irwin Jauwena dengan Direktur Utama PT Citilink Indonesia yang diwakili oleh Bapak Juliandra selaku Direktur Utama, kemudian diikuti dengan dilakukannya perubahan susunan organ perseroan baik Direksi maupun Dewan Komisari, yang pada dasaranya memasukkan 5 (lima) orang dari Garuda Group dari total 7 (tujuh) orang Direksi dan memasukkan 3 (tiga) orang dari Garuda Group dari total 7 (tujuh) 
orang Dewan Komisaris sebagaimana disebutkan dalam Akta Perubahan perseroan sebagai berikut:

1. Perubahan Susunan Pengurus PT Sriwijaya Air, berdasarkan Akta Pernyataan Keputusan Rapat PT Sriwijaya Air Nomor 06 Tanggal 10 Desember 2018 yang dibuat dihadapan Notaris Daniar Wasdiana, SH., MKn di Tangerang.

2. Perubahan Susunan Pengurus PT NAM Air, berdasarkan Akta Pernyataan Keputusan Sirkuler Para Pemegang Saham PT NAM Air Nomor 10 Tanggal 16 Januari 2019 yang dibuat dihadapan Notaris Daniar Wasdiana, SH., MKn di Tangerang.

Sehingga susunan organ perseroan PT Sriwijaya Air dan PT NAM Air setelah dilakukan perubahan pasca penandatanganan perjanjian KSM dapat dilihat sebagai berikut:

\section{$\underline{\text { PT Sriwijaya Air }}$}

Susunan Direksi terdiri dari 7 (tujuh) orang yaitu:

1. Tuan Josep Adriaan Saul selaku Direktur Utama Perseroan, yang merupakan perwakilan dari Garuda Group.

2. Tuan Harkandri M. Dahler selaku Direktur Human Capital \& Management Perseroan, yang merupakan perwakilan dari Garuda Group.

3. Tuan Amrulloh Hakiem selaku Direktur Keuangan Perseroan, yang merupakan perwakilan dari Garuda Group.

4. Tuan Joseph Dajoe K. Tendean sselaku Direktur Komersial/ Niaga Perseroan, yang merupakan perwakilan dari Garuda Group.

5. Tuan Fadjar Semiarto selaku Direktur Operasional, yang merupakan perwakilan dari Garuda Group.

6. Tuan Romdani selaku Direktur Teknik, yang merupakan perwakilan dari Sriwijaya Air.

7. Tuan Toto Soebandoro selaku Direktur Quality, Safety \& Security, yang merupakan perwakilan Sriwijaya Air.

Susunan Dewan Komisaris, terdiri dari 7 (tujuh) orang yaitu:

1. Tuan I Gusti Ngurah Askhara Danadiputra selaku Komisaris Utama Perseroan, yang merupakan wakil dari Garuda Group.

2. Tuan Lie Chandra selaku Wakil Komisaris Utama Perseroan, yang merupakan wakil dari Sriwijaya Air.

3. Tuan Pikti Ilham Kurniansyah selaku Komisaris Perseroan, yang merupakan wakil dari Garuda Group.

4. Tuan Ir. Juliandra, MM., selaku Komisaris Perseroan, yang merupakan wakil dari Garuda Group.

5. Tuan Hendry Lie selaku Komisaris Perseroan, yang merupakan wakil dari Sriwijaya Group.

6. Nyonya Sonia Xevianne Bongoro selaku Komisaris Perseroan, yang merupakan wakil dari Sriwijaya Air.

7. Tuan Jefferson Irwin Jauwena selaku Komisaris Perseroan, yang merupakan wakil dari Sriwijaya Air. 


\section{PT NAM Air}

Susunan Direksi, hanya terdiri dari 1 (satu) orang yaitu, yaitu Tuan Asa Perkasa selaku Direktur Perseroan, yang merupakan perwakilan dari Garuda Group.

Susunan Dewan Komisaris, hanya terdiri dari 1 (satu) orang yaitu Tuan Hendry Lie selaku Komisaris Perseroan, yang merupakan perwakilan dari Pemegang Saham PT NAM Air.

Perubahan terhadap susunan organ perseroan yang menempatkan orang-orang Garuda Group dalam susunan Direksi dan Dewan Komisaris tentu saja dampak yang cukup besar terhadap jalannya perusahaan Sriwijaya Group. Dimana sesuai dengan ketentuan peraturan perundangundangan dan anggaran dasar PT Sriwijaya Air dan PT NAM Air, bahwa Direksi-lah yang berwenang dan bertanggung jawab penuh atas pengurusan Perseroan untuk kepentingan Perseroan, dengan itikad baik dan kehati-hatian sesuai dengan maksud dan tujuan Perseroan serta mewakili Perseroan, baik di dalam maupun di luar pengadilan sesuai dengan anggaran dasar perseroan, sebagaimana tertuang dalam Pasal 92 ayat (1) dan ayat (2) UUPT yang berbunyi sebagai berikut:

$$
\begin{aligned}
& \text { ayat (1) "Direksi menjalankan pengurusan Perseroam untuk kepentingan } \\
& \text { Perseroan dan sesuai dengan maksud dan tujuan Perseroan". } \\
& \text { ayat (2) "Direksi berwenang menjalankan pengurusan Perseroan untuk } \\
& \text { kepentingan Perseroan dan sesuai dengan maksud dan tujuan } \\
& \text { Perseroan". }
\end{aligned}
$$

Yang diatur juga dalam Pasal 12 ayat (1) Anggaran Dasar Perubahan PT Sriwijaya Air, berdasarkan Akta Nomor 99 Tanggal 21 Agustus 2017 yang dibuat dihadapan Notaris Dr. Irawan Soerodjo, SH., MSi., di Jakarta, yang berbunyi sebagai berikut:

"Direksi berhak mewakili Perseroan di dalam dan di luar Pengadilan tentang segala hal dan dalam segala kejadian, mengikat Perseroan dengan pihak lain dan pihak lain dengan Perseroan, serta menjalankan segala tindakan, baik mengenai kepengurusan maupun kepemilikan dengan pembatasan bahwa untuk:

a. meminjam atau meminjamkan uang atas nama Perseroan (tidak termasuk mengambil uang Perseroan di Bank);

b. mendirikan suatu usaha baru atau turut serta pada perusahaan lain baik di dalam maupun di luar negeri;

-harus dengan persetujuan dari Dewan Komisaris".

Sebagaimana diatur juga dalam Anggaran Dasar PT NAM Air yang dituangkan dalam Pasal 12 ayat (1) Akta Pendirian PT NAM Air, berdasarkan Akta Nomor 3 Tanggal 2 Mei 2012 yang dibuat dihadapan Notaris Hj. Esti Paranti, SH., MKn., di Jakarta, yang berbunyi:

"Direksi berhak mewakili Perseroan di dalam dan di luar Pengadilan tentang segala hal dan dalam segala kejadian, mengikat Perseroan dengan pihak lain dan dalam segala kejadian, mengikat Perseroan dengan pihak lain dan pihak lain 
dengan Perseroan, serta menjalankan segala tindakan, baik yang mengenai kepengurusan maupun kepemilikan, akan tetapi dengan pembatasan bahwa untuk:

a. Meminjam atau meminjamkan uang atas nama Perseroan (tidak termasuk mengambil uang Perseroan di Bank).

b. Mendirikan suatu usaha baru atau turut serta pada perusahaan lain baik di dalam maupun di luar begeri.

-maka haruslah dengan persetujuan dari Dewan Komisaris Perseroan."

Akan tetapi bukan berarti kewenangan Direksi untuk mewakili Perseroan tidak ada pembatasan, karena dalam hal tertentu Direksi tidak berwenang mewakili Perseroan sebagaimana diatur dalam Pasal 99 ayat (1) UUPT yang berbunyi sebagai berikut:

"Anggota Direksi tidak berwenang mewakili Perseroan apabila:

a. $\quad$ terjadi perkara di pengadilan antara Perseroan dengan anggota Direksi yang bersangkutan; atau

b. anggota Direksi yang bersangkutan mempunyai benturan kepentingan dengan Perseroan"

Asas itikad baik sendiri tertuang dapat disimpulkan dari Pasal 1338 ayat (3) KUH Perdata yang berbunyi: "Perjanjian harus dilaksanakan dengan itikad baik." Asas itikad baik merupakan asas bahwa para pihak harus melaksanakan subtansi kontrak berdasarkan kepercayaan atau keyakinan yang teguh atau kemauan baik dari para pihak. ${ }^{2}$

Tindakan Direksi Sriwijaya Group yang adalah orang-orang Garuda Group sendiri dalam melakukan perubahan terhadap Perjanjian Perubahan dan Pernyataan Kembali Perjanjian Kerja Sama Operasi Nomor CITILINK/JKTDSQG/AMAND-I/6274/1118 Tanggal 19 November 2018 antara PT Citilink Indonesia dengan PT Sriwijaya Air dan PT NAM Air, yakni dengan menyepakati Amandement II dan Amandemen III Perjanjian KSM tanpa adanya persetujuan Para Pemegang Saham Sriwijaya Group sejak awal sangat erat kaitannya dengan pelaksanaan fungsi dan wewenang Direksi berdasarkan asas itikad baik, dimana Direksi yang menandatangani Amandemen II dan Amandemen III Perjanjian KSM adalah orang-orang Garuda Group yang ditempatkan di Sriwijaya Group, yang mewakili 2 (dua) kepentingan yaitu kepentingan Garuda Group dan kepentingan Sriwijaya Group.

Jika melihat dari prinsip-prinsip Business Judgement Rule, dimana guna memenuhi asas kehatihatian oleh Direksi Sriwijaya Group yang merupakan orang-orang Garuda Group, sebagaimana diatur dalam Pasal 99 ayat (1) huruf b, yang menyatakan bahwa: "Anggota Direksi tidak berwenang mewakili Perseroan apabila anggota Direksi yang bersangkutan mempunyai benturan kepentingan dengan Perseroan". Artinya dikarena Tuan Josep Adriaan Saul selaku Direktur Utama PT Sriwijaya Air dan Tuan Asa Perkasa selaku Direktur PT NAM Air yang juga adalah orang-orang Garuda Group, maka sudah selayaknyalah Tuan Josep Adriaan Saul selaku Direktur Utama PT Sriwijaya Air dan Tuan Asa Perkasa selaku Direktur PT NAM Air terlebih dahulu

${ }^{2}$ Salim H. S., Hukum Kontrak Teori \& Teknik Penyusunan Kontrak, (Jakarta: Sinar Grafika, 2017), hlm. 911. 
meminta persetujuan dari Pemegang Saham Sriwijaya Group sebelum menyepakati dan/atau menandatangani Amandemen II dan Amandemen III dari Perjanjian KSM, karena tidak dapat dipungkiri terkait Amandemen II dan Amandemen III menyangkut kepentingan Sriwijaya Group dan PT Citilink Indonesia (Garuda Group) yang mana kedua Direktur tersebut (Tuan Joseph Adriaan Saul dan Tuan Asa Perkasa) sudah seharusnya memahami bahwa posisi kedua Direktur tersebut selain merupakan Direktur Sriwijaya Group juga adalah orang-orang Garuda Group, yang mana Garuda Group juga memiliki kepentingan bisnis dengan Sriwijaya Group, sehingga sikap hati-hati dari kedua Direktur tersebut sangatlah dituntut dalam hal pengambilan keputusan khususnya terkait kerja sama KSM atau kerja sama lainnya yang sedang atau akan dibuat dengan Garuda Group.

Direksi Sriwijaya Group yang adalah orang-orang Garuda Group ditempatkan di Sriwijaya Group dengan satu alasan yaitu karena adanya kerja sama KSM. Sehingga keberadaan orangorang Garuda Group dalam susunan organ perseroan Sriwijaya Group seharusnya menjadi hal yang dapat menciptakan terwujudnya kerja sama yang saling menguntungkan diantara para pihak yaitu Sriwijaya Group dan Garuda Group. Akan tetapi tidak dapat dihindari bahwa orangorang Garuda Group yang ada di dalam susunan organ perseroan Sriwijaya Group tetaplah tidak dapat dipisahkan dengan adanya kepentingan Garuda Group di dalamnya, sehingga orang-orang Garuda Group yang ditempatkan dalam susunan organ perseroan Sriwijaya Group baik itu susunan Direksi maupun susunan Dewan Komisaris haruslah menjunjung tinggi asas itikad baik sebagaimana diatur dalam Pasal 1338 ayat (3) KUH Perdata yang berbunyi "Perjanjian harus dilaksanakan dengan itikad baik" sehingga diharapkan keputusan bisnis yang diambil adalah keputusan bisnis yang tepat.

Sebuah pendapat mengatakan "Penghormatan keputusan bisnis yang beritikad baik disebut dengan Business Judgement Rule (BJR). Perkataan ini tampak mengkaitkan itikad baik harus ada dalam semua keputusan bisnis yang dibuat oleh Direktur Sriwijaya Group yang adalah wakil dari Garuda Group. Pendapat ini tidak dapat disangkal kebenarannya. Dalam kasus Chew v R dikatakan bahwa kewajiban direktur untuk bertindak dengan itikad baik mempunyai sejumlah komponen yang disyaratkan, yaitu: ${ }^{3}$

1. Bertindak secara jujur

2. Melaksanakan kekuasaan untuk kepentingan perusahaan dan menghindari penyalahgunaan kekuasaan tersebut

3. Menghindari Conflict of Interest

Ketiga syarat di atas sudah cukup membuktikan bahwa semua standar yang dipakai dalam Business Judgement Rule mengandung konsep itikad baik. Itikad baik menjadi berlaku secara universal. Itikad baik dalam kaitannya dengan BJR adalah:

1. Direktur Sriwijaya Group yang adalah orang Garuda Group dikatakan tidak beritikad baik dalam keputusan yang diambilnya apabila direktur mengabaikan semua fakta-fakta yang relevan dengan keputusannya, sebagai contoh: Direktur Utama PT Sriwijaya Air dan Direktur PT NAM Air yang adalah orang-orang Garuda Group membuat Amandemen II terkait besaran Management Fee dan Bagi Hasil yang cukup memberatkan kondisi finansial

\footnotetext{
${ }^{3}$ Robert Prayoko, DOKTRIN BUSINESS JUDGMENT RULE Alikasinya dalam Hukum Perusahaan Modern, Cetakan I, (Yogyakarta: Graha Ilmu, 2015), hlm. 85.
} 
Sriwijaya Group, dan hal tersebut dimungkinan dilakukan karena adanya conflict of interest dimana selain mereka adalah Direktur Sriwijaya Group mereka juga adalah orang-orang Garuda Group.

2. Direktur Sriwijaya Group yang adalah orang Garuda Group dikatakan tidak beritikad baik apabila mengutamakan kepetingan pihak ketiga tanpa mempertimbangkan kepentingan perusahaan.

3. Direktur Sriwijaya Group yang adalah orang Garuda Group beritikad baik apabila dirinya mengambil langkah positif, misalnya ketika Direktur tersebut menyadari bahwa Amandemen II yang dibuat akan membahayakan kondisi finansial perusahaan, maka direktur justru harus mengambil langkah-langkah untuk mencegah terjadinya kerugian perusahaan atau setidaknya meminta persetujuan para pemegang saham berhubungan dengan pengambilan keputusan terkait pembuatan Amandemen II dan III untuk menghindari anggapan adanya conflict of interest dalam hubungannya dengan pengambilan keputusan Direktur Sriwijaya Group yang adalah orang-orang wakil dari Garuda Group.

Hal ini tidak lain juga berkaitan dengan permasalahan batas-batas seorang Direktur dapat dimintai pertanggungjawabannya secara pribadi atas keputusan bisnis yang diambilnya. UUPT memberikan tanggung jawab secara pribadi kepada direktur manakala terjadi pelanggaran. Standar Keputusan Bisnis Pasal 97 ayat 5 memberikan standar yang membebaskan direktur untuk bertanggung jawab secara pribadi.

Sehingga, Direktur Sriwijaya Group yang adalah orang-orang Garuda Group hendaknya meminta persetujuan terlebih dahulu dengan Para Pemegang Saham Sriwijaya Group dalam hal Direktur tersebut akan melakukan transaksi atau kesepakatan kerja sama dalam hal apapun yang berkaitan dengan pihak Garuda Group, hal ini diharapkan mampu untuk menghindarkan Direktur Sriwijaya Group yang adalah orang Garuda Group dimintai pertanggungjawaban secara pribadi nantinya, karena seorang Direktur tidak dapat dianggap sebagai seseorang yang mempunyai tanggung jawab personal sebagai seorang direktur manakala mereka melakukan tindakan sesuai dengan perintah pemegang saham. ${ }^{4}$

Direktur Sriwijaya Group yang adalah orang-orang Garuda Group tersebut harus menghindari untuk menempatkan diri mereka dalam posisi dimana kepentingan mereka atau kepentingan pihak lainnya (katakanlah kepentingan Garuda Group) bertentangan dengan kepentingan Perusahaan, karena Direksi adalah organ yang diberi tugas dan kewajiban oleh undang-undang untuk melakukan kegiatan menjalankan kepengurusan (manajemen) perseroan terbatas sesuai tujuan dan maksud pendiriannya. Di samping tugas dan kewajibannya tersebut, undang-undang juga hanya memberikan hak dan kewenangan bertindak kepada direksi dalam status untuk dan atas nama mewakili kepentingan perseroan terbatas, dimana dalam menjalankan tugas, kewajiban, hak dan kewenangannya tersebut, direksi senantiasa berada di bawah pengawasan dewan komisaris. Dalam hal ini Direktur Sriwijaya Group yang adalah orang-orang Garuda Group tidak boleh menggunakan posisi mereka dalam perusahaan untuk mendapatkan keuntungan pribadi atau untuk keuntungan pihak lainnya misalkan saja kepentingan semata-mata dari Garuda Group.

\footnotetext{
${ }^{4}$ Ibid., hlm. 90.
} 
Ketidaksetujuan Para Pemegang Saham Sriwijaya Group sendiri terlihat dari tindakan nyata Para Pemegang Saham yaitu dengan mengambil langkah berupa melakukan perubahan anggaran dasar perseroan terkait kewenangan Direksi yang semula dalam Akta Nomor 99 Tanggal 21 Agustus 2017 yang dibuat dihadapan Notaris Dr. Irawan Soerodjo, SH., MSi di Jakarta diubah melalui Akta Nomor 15 Tanggal 18 Maret 2019 yang dibuat dihadapan Daniar Wasdiana, SH., MKn., di Tangerang, yang membatasi kewenangan Direksi yang pada intinya Menyetujui Penambahan dan/atau Perubahan Tugas dan Wewenang Direksi sehubungan dengan Pasal 12 Tugas dan Wewenang dalam ayat (1) Anggaran Dasar Perseroan, sebagaimana dijelaskan berikut ini:

Semula dalam Pasal 12 ayat (1) Akta Nomor 99 Tanggal 21 Agustus 2017 yang dibuat dihadapan Notaris Dr. Irawan Soerodjo, SH., MSi di Jakarta, yang berbunyi sebagai berikut:

"Direksi berhak mewakili Perseroan di dalam dan di luar Pengadilan tentang segala hal dan dalam segala kejadian, mengikat Perseroan dengan pihak lain dan pihak lain dengan Perseroan, serta menjalankan segala tindakan, baik mengenai kepengurusan maupun kepemilikan, dengan pembatasan bahwa untuk:

a. meminjam atau meminjamkan uang atas nama Perseroan (tidak termasuk mengambil uang Perseroan di Bank);

b. mendirikan suatu usaha baru atau turut serta pada perusahaan lain baik di dalam maupun di luar negeri.

-harus dengan persetujuan dari Dewan Komisaris."

Untuk selanjutnya diubah Berdasarkan Pasal 12 Ayat (1) Akta Nomor 15 Tanggal 18 Maret 2019 Yang Dibuat Dihadapan Daniar Wasdiana, SH., Mkn., di Tangerang, sehingga menjadi berbunyi sebagai berikut:

"Direksi berhak mewakili Perseroan didalam dan diluar Pengadilan tentang segala hal dan dalam segala kejadian, mengikat Perseroan dengan pihak lain dan pihak lain dengan Perseroan, serta menjalankan segala tindkan, baik yang mengenai kepengurusan maupun kepemilikan, akan tetapi dengan pembatasan bahwa untuk:

a. meminjam atau meminjamkan uang atas nama Perseroan (tidak termasuk mengambil uang perseroan di Bank);

b. memindahtangankan dan menghapuskan aktiva tetap milik Perseroan dengan nilai di atas $R p$. 100.000.000,- (seratus juta rupiah);

c. mendirikan suatu usaha baru atau turut serta pada perusahaan lain baik di dalam maupun di luar negeri;

d. membuka rekening koran pada bank, termasuk mengusulkan specimen bank akan dipergunakan oleh Perseroan dan/atau anak-anak perusahaan milik Perseroan;

e. membeli, menjual atau dengan cara lain melepaskan hak-hak atas harta tetap dan perusahaan-perusahaan atau membebani harta kekayaan Perseroan, yang nilainya kurang dari atau sampai dengan 10\% (sepuluh persen) dari harta kekayaan Perseroan;

f. mengikat Perseroan sebagai penjamin yang nilainya kurang dari atau sampai dengan 10\% (sepuluh persen) dari harta kekayaan Perseroan;

g. mengadakan kerjasama dengan badan usaha atau pihak lain dalam bentuk kerjasama operasi, kontrak manajemen, kerjasama lisensi Bangun Guna Serah (Building, Operate 
Otentik's: Jurnal Hukum Kenotariatan (Vol 3, No. 2, Juli 2021)

p-ISSN 2655-5131 e-ISSN 2685-3612

and Transfer/BTO), Bangun Guna Milik (Build, Operate and Own/BOO) dan perjanjian-perjanajian lain yang mempunyai sifat yang sama untuk jangka waktu tertentu;

h. melakukan pengeluaran uang perusahaan sehubungan dengan kerjasama operasi, kontrak manajemen, kerjasama lisensi Bangun Guna Serah (Building, Operate and Transfer/BTO), Bangun Guna Milik (Build, Operate and Own/BOO) dan perjanjianperjanjian lain yang mempunyai sifat yang sama untuk jangka wkatu tertentu;

$i$. menerima atau memberikan pinjaman jangka menengah atau panjang dengan nilai di atas Rp. 1.000.000.000,- (satu miliar rupiah), dengan atau tanpa jaminan, kecuali pinjaman utang atau piutang yang timbul karena transaksi binsnis dan pinjaman yang diberikan kepada anak perusahaan Perseroan;

j. menghapuskan dari pembukuan piutang macet dan persediaan barang mati, dengan nilai di atas Rp. 100.000.000,- (seratus juta rupiah);

k. membentuk yayasan, organisasi dan/atau perkumpulan baik yang berkaitan langsung maupun tidak langsung dengan Perseroan yang dapat berdampak finansial bagi Perseroan;

l. membebankan biaya Perseroan yang bersifat tetap dan rutin untuk kegiatan yayasan, organisasi dan/atau perkumpulan baik yang berkaitan langsung maupun tidak langsung dengan Perseroan;

m. mengusulkan wakil Perseroan untuk menjadi calon anggota Direksi dan Dewan Komisaris pada anak perusahaan yang memberikan konrtribusi signifikan kepada Perseroan dan/atau bernilai strategis;

n. tidak lagi menagih piutang macet yang telah dihapusbukukan, dengan nilai di atas Rp. 100.000.000,- (seratus juta rupiah);

o. menetapkan dan mengubah logo Perseroan;

p. melepaskan penyertaan modal pada anak perusahaan, sepanjang hal tersebut tidak memerlukan persetujuan dari RUPS;

q. melakukan penggabungan, peleburan, pengambilalihan, pemisahan dan pembubaran anak perusahaan, sepanjang hal tersebut tidak memerlukan persetujuan dari RUPS;

$r$. menetapkan gaji, pensiun atau jaminan hari tua dan penghasilan lain bagi pegawai Perseroan yang melampaui kewajiban yang ditetapkan dalam peraturan perundangundangan;

s. mengikat Perseroan sebagai penjamin (Borg atau avalist) yang mempunyai akibat keuangan yang melebihi jumlah tertentu yang ditetapkan oleh Dewan Komisaris;

t. menetapkan (mengangkat dan memberhentikan) struktur organisasi sampai dengan 1 (satu) tingkat di bawah Direksi;

u. mengusulkan dan/atau menunjuk akuntan publik (auditor independent);

-harus mendapat persetujuan dari Dewan Komisaris."

Walaupun terkesan terlambat dalam pengambilan langkah Para Pemegang Saham Sriwijaya Group tetapi melakukan perubahan terhadap Anggaran Dasar Perseroan tetap dilakukan yaitu berupa pengaturan secara terperinci Pasal 12 ayat (1) Anggaran Dasar Perseroan tentang Tugas dan Wewenang Direksi. Hal ini merupakan salah satu tindakan antisipatif yang dilakukan Para Pemegang Saham Sriwijaya Group dalam menghindakan Direksi dari orang-orang Garuda Group melakukan tindakan pengurusan perseroan yang didasarkan atas adanya konflik 
kepentingan (conflict of interest), yang mana seharusnya tindakan tersebut dilakukan oleh Pemegang Saham Sriwijaya Group sebelum terjadinya penandatanganan Amandemen II dan Amandemen III Perjanjian KSM.

Kurangnya persiapan dari Para Pemegang Saham Sriwijaya Group dapat terlihat dari keputusan Para Pemegang Saham Sriwijaya Group yang mengatur secara rinci Tugas dan Wewenang Direksi saat Direkso dari orang-orang Garuda Group telah melakukan amandemen terhadap Perjanjian KSM, yang mana amandemen II dan amandemen III yang dibuat justru memberatkan posisi Sriwijaya Group.

Adapun hal-hal yang penting untuk diantisipasi oleh Perseroan melalui Pemegang Saham diantaranya terdiri dari 3 (tiga) fase, yaitu:

1. Fase Pertama yaitu sebelum dibuat dan ditandatanganinya perjanjian kerja sama (pra contract)

2. Fase Kedua yaitu saat pelaksanaan kerja sama

3. Fase Ketiga yaitu setelah kerja sama berlangsung (pasca contract)

\section{KESIMPULAN}

Adapun kesimpulan yang dapat penulis sampaikan yaitu sebagai berikut:

1. Tindakan yang dilakukan Direksi Sriwijaya Group yang merupakan orang-orang Garuda Group dengan melihat pada kasus penandatanganan Amandemen II dan Amandemen III Perjanjian Perubahan dan Pernyataan Kembali Perjanjian Kerja Sama Operasi Nomor CITILINK/JKTDSQG/AMAND-I/6274/1118 Tanggal 19 November 2018 antara PT Citilink Indonesia dengan PT Sriwijaya Air dan PT NAM Air (Perjanjian "KSM"), dengan tidak meminta persetujuan terlebih dahulu dari Pemegang Saham Sriwijaya Group dapatlah dianggap tidak didasarkan atas prinsip Business Judgement Rule sebagai cerminan dari pelaksanaan asas itikad baik, karena selain membawa kepentingan Garuda Group karena mereka adalah orang-orang Garuda Group yang ditempatkan di Srwiijaya Group, mereka juga berada dalam susunan organ perseroan (Direksi dan Dewan Komisaris) Sriwijaya Group yang tentunya juga harus memperjuangkan kepentingan perseroan Sriwijaya Group.

2. Terkait pelaksanaan perjanjian KSM, dengan melihat kasus posisi yang terjadi, dimana Sriwijaya Group mengangkat orang-orang Garuda Group dalam susunan organ perseroan akan tetapi tidak terlebih dahulu membuat aturan yang terperinci sehubungan dengan tugas dan kewenangan Direksi dalam anggaran dasar perseroan serta tidak mengatur secara jelas terkait klausul-klausul dalam perjanjian KSM dan terlambat dalam melakukan pengaturan yang terperinci terkait Tugas dan Wewenang Direksi, sehingga mengakibatkan tindakan Direksi Sriwijaya Group yang adalah orang-orang Garuda Group dapat melakukan intervensi terhadap kerja sama KSM yang justru memberatkan posisi Sriwijaya Group sebagai pihak dalam perjanjian KSM. 


\section{SARAN}

Saran dari hasil penelitian ini diharapkan juga bermanfaat dan memberikan sumbangan positif bagi dunia pendidikan dan juga khususnya para pelaku usaha yang bertujuan membangun kerja sama sejenis berupa Kerja Sama Operasi atau Kerja Sama Pengelolaan Management atau bentuk kerja sama sejenis lainnya antara perseroan yang satu dengan perseroan lainnya. Adapun saran yang Peneliti akan sampaikan didasarkan pada kesimpulan dan uraian dari bab-bab terdahulu adalah sebagai berikut:

1. Peran Direksi Sriwijaya Group yang adalah orang-orang dari Garuda Group dalam periode jangka waktu pelaksanaan perjanjian KSM sangatlah penting, sehingga sudahlah sewajarnya dalam melaksanana tugas dan wewenangnya baik sebagai Direksi maupun Dewan Komisaris PT Sriwijaya Air, orang -orang Garuda Group yang ditempatkan dalam organ perseroan Sriwijaya Group harus mengambil tindakan dengan memperhatikan prinsip Business Judgement Rule sebagai cerminan dari pelaksanaan asas itikad baik. Direksi dalam menjalankan tugas dan fungsinya hendaknya memperhatikan hal-hal yang patut untuk dilaksanakan dan bersikap jujur dalam setiap keputusan perusahaan yang akan diambil khususnya terkait dengan kerja sama KSM. Dalam melaksanakan tugas dan wewenangnya, karena Direksi dan Komisari yang adalah orang-orangg Garuda Group berada di atas 2 (dua) kepentingan sudahlah seharusnya setiap keputusan bisnis terkait kerja sama KSM dapat disetujui terlebih dahulu oleh pemegang saham Sriwijaya Group, kecuali ada pengecualian dari pemegang saham Sriwijaya Group sendiri. Hal ini bertujuan untuk menjaga agar kerja sama KSM dapat terwujud sesuai dengan tujuan dari kerja sama dimaksud dan saling menguntungkan bagi para pihak, serta menghindarkan orang-orang Garuda Group yang ditempatkan di Sriwijaya Group dari tuntutan hukum yang kemudian hari dapat mungkin saja diajukan oleh pemegang saham akibat dari tindakan yang dianggap tidak didasarkan atas prinsip Business Judgement Rule sebagai bentuk cerminan dari asas itikad baik.

2. Sebelum membuat Kerja Sama Pengelolaan Management atau kerja sama sejenis lainnya, maka guna melindungi kepentingan perseroan sudahlah sewajarnya jika perseroan dalam hal ini melalui pemegang saham memperhatikan dengan seksama halhal apa saja yang penting untuk diatur dan dipersiapkan baik pada masa saat sebelum kerja sama dibuat dan ditandatangani, saat kerja sama berlangsung dan saat kerja sama berakhir.

Hal yang penting untuk dilakukan pada fase saat sebelum kerja sama dibuat dan ditandangani (pra contract) diantaranya adalah agar Pemegang Saham terlebih dahulu merumuskan bentuk kerja sama secara detail dan menyeluruh sesuai dengan tujuan dari dibentuknya kerja sama sebelum dilakukan pendandatanganan terhadap perjanjian KSM.

Hal yang penting untuk dilakukan pada fase saat kerja sama berlangsung diantaranya jika RUPS menyetujui untuk mengangkat Direksi dan Dewan Komisaris dari orangorang Garuda Group adalah membuat batasan yang jelas dalam anggaran dasar perseroan terkait tugas dan wewenang Direksi dan juga Dewan Komisaris, sehingga diharapkan hal tersebut mampu untuk menjadi salah satu alat kontrol dalam 
pengambilan keputusan bisnis yang dilakukan oleh Direksi perseroan Sriwijaya Group dalam hal ini yang adalah orang-orang dari Garuda Group.

Hal yang penting untuk dilakukan pada fase saat kerja sama telah dilaksanakan/ telah berakhir ( pasca contract) diantaranya adalah dapat melakukan audit independent atau evaluasi secara bersama antara organ perseroan Sriwijaya Group dalam hal ini oleh para pemegang saham dengan management PT Citilink Indonesia (Garuda Group) untuk mengetahui efektifitas dari kerja sama KSM. Pada fase ini juga pemegang saham melalui organ perseroan RUPS dapat melakukan penyesuaian kembali terhadap organ perseroan yang ada.

Berdasarkan uraian sebagaimana disampaikan oleh penulis, diharapkan memberikan sumbangan pemikiran terhadap suatu kerja sama management yang akan dilakukan oleh badan hukum lainnya, sehingga tujuan dari dibentuknya kerja sama dapat tetap terlaksana sebagaimana mestinya.

\section{DAFTAR PUSTAKA}

\section{Buku}

Abdulkadir Muhammad, Hukum dan Penelitian Hukum, (Bandung: PT Citra Aditya Bakti, 2004).

Robert Prayoko, DOKTRIN BUSINESS JUDGMENT RULE Alikasinya dalam Hukum Perusahaan Modern, Cetakan I, (Yogyakarta: Graha Ilmu, 2015).

Salim H. S., Hukum Kontrak Teori \& Teknik Penyusunan Kontrak, (Jakarta: Sinar Grafika, 2017).

\section{Perundang-Undangan}

Kitab Undang-Undang Hukum Perdata.

Undang-Undang Nomor 40 Tahun 2007 Tentang Perseroan Terbatas. 